\title{
Effects of elevated temperature and sedimentation on grazing rates of the green sea urchin: implications for kelp forests exposed to increased sedimentation with climate change
}

\author{
Sarah B. Traiger ${ }^{*}$ (D)
}

\begin{abstract}
Sea urchin grazing rates can strongly impact kelp bed persistence. Elevated water temperature associated with climate change may increase grazing rates; however, these effects may interact with local stressors such as sedimentation, which may inhibit grazing. In Alaska, glacial melt is increasing with climate change, resulting in higher sedimentation rates, which are often associated with lower grazer abundance and shifts in macroalgal species composition. The short-term effects of elevated temperature and sediment on grazing were investigated for the green sea urchin,

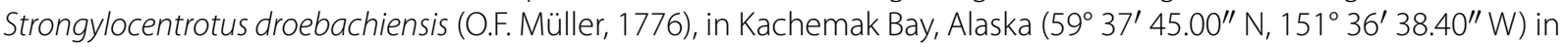
early May 2017. Feeding assays were conducted at ambient temperature $\left(6.9-9.8^{\circ} \mathrm{C}\right)$ and at $13.8-14.6^{\circ} \mathrm{C}$ with no sediment and under a high sediment load. Grazing rates significantly decreased in the presence of sediment, but were not significantly affected by temperature. Along with sediment impacts on settlement and post-settlement survival, grazing inhibition may contribute to the commonly observed pattern of decreased macroinvertebrate grazer abundance in areas of high sedimentation and increased sedimentation in the future may alter sea urchin grazing in kelp forests.
\end{abstract}

Keywords: Temperature, Sediment, Strongylocentrotus, Grazing

\section{Introduction}

Kelp forests are critical biogenic habitats distributed along temperate and polar coasts worldwide that support high biodiversity [1]. Sea urchins are frequently the most important consumers within kelp forest communities and exert top-down control on kelp distribution, abundance, and species composition [2]. Loss of urchin predators can lead to phase shifts from kelp forests to urchin barrens [2], alternative stable states with lower productivity and structural complexity than kelp forests $[3,4]$. Once formed, urchin barrens can persist for many decades due to continued high urchin densities and destructive grazing inhibiting kelp recovery [5].

*Correspondence: sarah.traiger@csun.edu

University of Alaska Fairbanks, 2150 Koyukuk Dr., PO Box 757220, Fairbanks, AK 99775, USA
Climate change is causing global and local changes in physical conditions which may have significant effects on sea urchins and their role in shaping kelp forests. Global mean sea surface temperature has increased by $1{ }^{\circ} \mathrm{C}$ over the last century [6] and is projected to continue increasing with continued fossil fuel use [7]. Marine invertebrate prey consumption rates are predicted to increase with elevated temperature due to increased metabolic rates within their thermal tolerance window [8]. Elevated temperature increases consumption rates of some marine invertebrates including gastropods [9], sea stars [10], and sea urchins [11]. Climate-induced increases in kelp consumption could threaten the persistence of productive kelp forests [12], although decreased herbivory and kelp recovery has also been observed in response to warming [13]. Sedimentation rates have increased or are predicted to increase in several kelp forest systems around 
the world due to changes in land-use or climate change (e.g. New Zealand [14], US Atlantic [15], Europe [16]). At high latitudes, glaciers are melting at accelerating rates [17], resulting in increased glacial discharge that delivers fine sediment to the nearshore environment [18]. As glacial melt increases with increasing air temperatures, the amount of sediment deposited in the nearshore environment could increase, or sediment plumes could spread farther, making these high-sediment conditions more common in kelp forests. In the Arctic, wind-induced water motion during longer ice-free summers has led to increased sediment resuspension [19] and erosion rates are expected to continue accelerating [20]. Sedimentation is an important driver of benthic community structure and can limit grazer abundance near points of glacial discharge in Alaska [21] and other high-sediment locations [22]. Lower grazer survival and/or grazing rates may contribute to this pattern. Sedimentation can scour tissues of invertebrate grazers, and may interfere with movement, attachment to substrate, and gas exchange [22]. Some macroalgae that are palatable to sea urchins (such as Saccharina latissima) persist near points of glacial melt despite high sediment loads [21, 23]. Because sedimentation rates are predicted to increase in the nearshore environment [15-17, 24], it is important to know how sedimentation affects urchin grazing rates to anticipate changes in herbivore-plant interactions in the future.

Kelp forest community responses to warming sea temperatures may vary with sediment load. Increased sea temperature may interact with local stressors and alter top-down effects in kelp forest systems in ways that cannot be predicted by studying the effects of global or local stressors alone. In low sediment areas, increased temperature could result in increased kelp consumption by urchins leading to reduced kelp biomass and contributing to the maintenance of urchin barrens [25-27]. High sedimentation may increase urchin energetic costs by reducing grazing efficiency or causing urchins to increase movement [22]. Temperature and sedimentation may have synergistic negative effects on urchins, if grazing rates cannot increase to meet metabolic needs in the presence of sediment. Although elevated temperature and other stressors can affect a wide range of species interactions [28] and other aspects of sea urchin populations such as recruitment and larval survival [29], here I focus on sea urchin grazing on kelp. This study investigated the effects of increased temperature and sediment load on grazing rates of the green sea urchin, Strongylocentrotus droebachiensis in Kachemak Bay, Alaska. The experiment tested three hypotheses: (1) grazing rates are higher at predicted temperature for the year $2030\left(14{ }^{\circ} \mathrm{C}\right.$, Hadley and Canadian climate models [30]) than ambient temperature $\left(6.9-9.8^{\circ} \mathrm{C}\right)$, (2) grazing rates are lower under high sediment conditions (1-cm thick layer of fine settled sediment) than without sediment, and (3) under combined conditions of future temperature and high sediment load, grazing rates are higher than those under ambient temperature and high sediment load.

\section{Materials and methods \\ Sample collections}

One adult Strongylocentrotus droebachiensis (30-40 mm test diameter, $14.95 \mathrm{~g}$ mean wet weight $\pm 0.57 \mathrm{SE}, n=36$ ) was used in each treatment. Urchins were collected from 10-m depth mean lower low water (MLLW) from an urchin barren on the northern coast of Kachemak Bay $\left(59^{\circ} 37^{\prime} 45.00^{\prime \prime} \mathrm{N}, 151^{\circ} 36^{\prime} 38.40^{\prime \prime} \mathrm{W}\right)$ on $4 / 28 / 2017$, transported to the Kasitsna Bay Laboratory and held in a tank with ambient flow-through sea water. While in the holding tank, urchins were fed Saccharina latissima collected from the shallow subtidal $(2-3 \mathrm{~m})$ at Kasitsna Bay to satiation each day. Urchins were held in the laboratory for 8 , 14, or 19 days before the first, second, and third runs of the experiment, respectively. Urchins were then moved to experimental jars (1-L mason jars with mesh-covered openings to allow water exchange) and starved, and the temperature was gradually increased to $14{ }^{\circ} \mathrm{C}$ over 2 days in the elevated temperature treatment. Urchins in ambient temperature treatment were also held in experimental jars during this time and were exposed to ambient temperature. This resulted in a starvation period of 2 days for urchins in all treatments. At the start of the grazing trial, $\sim 5 \mathrm{~g}(4.98 \pm 0.12$, mean $\pm \mathrm{SE}, n=72)$ of S. latissima were added to each jar and weighed down with a small rock, just before sediment was added. Sediment was collected from the shallow subtidal $(2-3 \mathrm{~m})$ at Kasitsna Bay, dried and sieved to retain fine sediment $<63 \mu \mathrm{m}$, then $6 \mathrm{~g}$ was sprinkled over the top of the jar to distribute it evenly, forming a $1-\mathrm{cm}$ thick layer $\left(1600 \mathrm{mg} \mathrm{cm}^{-2}\right)$ in the bottom of the experimental jar at the start of the experiment. This also resulted in a thin film of sediment ( $<1$-mm thick) on the piece of kelp in the jar.

\section{Experimental design}

Two temperature levels (ambient $\left[6.9-9.8{ }^{\circ} \mathrm{C}\right]$ and elevated $\left[14{ }^{\circ} \mathrm{C}\right]$ ) and two sediment load levels (no sediment and high (1-cm thick layer)) were manipulated in a crossed design for a total of four treatment combinations $(\mathrm{n}=3$ per treatment) during three experimental runs $(5 / 6-5 / 8,5 / 12-5 / 14$, and 5/17-5/19/2017). Each treatment had a paired no-urchin control which was used in grazing rate calculations. The elevated temperature level is approximately $2{ }^{\circ} \mathrm{C}$ above the average summer high temperature in Kachemak Bay, Alaska (based on average temperature during the warmest 24 -h period in each year from 2002 to 2014 [31]) and is the expected summer high 
temperature for the year 2030 [32]. The sediment treatments are based on observations of sediment layers on rocks at sites downstream of glacial melt (Traiger pers obs).

In the first two experimental runs, twelve 1-L mason jars were placed in each of two plastic tanks $(91 \times 41 \times 38 \mathrm{~cm})$. One tank contained a tank heater set at $14{ }^{\circ} \mathrm{C}$ for the high temperature treatment, while the other tank was the ambient temperature control. Unfiltered seawater was pumped into the laboratory from Kasitsna Bay, flowed into each tank through one hose placed at the center of the tank and flowed out through the top of the tank. Three replicates of sediment treatment jars (six mason jars, half with urchins and half without urchins) were placed in each tank. For the third run, additional heaters became available, so a total of six glass tanks $(51 \times 30 \times 25 \mathrm{~cm})$ were used, three of which contained a heater, with one replicate of each sediment treatment (four mason jars, half of which were nourchin controls) in each tank. Jars were randomly positioned within all aquaria. Sea water flow rates through each tank were maintained at approximately $20 \mathrm{~mL} \mathrm{~s}^{-1}$ to allow water circulation throughout the tank, but to prevent sediment from dispersing out of the mason jars for all experimental runs. One Honest Observer by Onset (HOBO) Pendant data logger (Onset Computers, Bourne, Massachusetts) was floated at the surface of each tank and temperature was recorded hourly. Only five loggers were available, so the ambient tank number 5 was randomly selected as the tank for which no temperature data were collected (Table 1). There were three replicates of each of the four treatments (ambient temperature and no sediment, ambient temperature and high sediment, elevated temperature and no sediment, and elevated temperature and high sediment) per experimental run. The jars without urchins are not considered a treatment here because those data were used in the calculation of grazing rates.

After each experiment the remaining S. latissima were weighed and feeding rates (mg kelp g urchin ${ }^{-1} \mathrm{~h}^{-1}$ ) for each replicate were calculated using the formula: $\mathrm{F}=\left[\left(\mathrm{F}_{0}-\mathrm{F}_{\mathrm{t}}\right)-\left(\mathrm{F}_{\mathrm{b} 0}-\mathrm{F}_{\mathrm{bt}}\right)\right] / \mathrm{WT}$, where $\mathrm{F}_{0}$ and $\mathrm{F}_{\mathrm{t}}$ are the start and end kelp weights with an urchin, $\mathrm{F}_{\mathrm{b} 0}$ and $\mathrm{F}_{\mathrm{bt}}$ are the start and end weights of kelp in the paired no-urchin control jar, $\mathrm{W}$ is the urchin weight, and $\mathrm{T}$ is the experiment duration [33].

\section{Statistical analysis}

Grazing rates were compared among treatments using a linear mixed effects model (lme4 package [34]) in $R$ Studio version 1.1.456 [35]. Temperature (levels: ambient, elevated) and sediment (levels: no sediment, high sediment) were fixed factors and tank (10 tanks) nested
Table 1 Average temperature ( \pm standard error) in each experimental tank. Only five loggers were available, so the ambient tank 5 was randomly selected as the tank for which no temperature data were collected

\begin{tabular}{ll}
\hline Treatment & $\begin{array}{l}\text { Average temperature } \\
\left({ }^{\circ} \mathbf{C}\right) \pm \text { standard error }\end{array}$ \\
\hline Ambient & \\
Run 1, Tank 1 & $6.86 \pm 0.02$ \\
Run 2, Tank 3 & $7.62 \pm 0.03$ \\
Run 3 & \\
Tank 5 & No data \\
Tank 6 & $9.76 \pm 0.21$ \\
Tank 7 & $8.96 \pm 0.18$ \\
Elevated & \\
Run 1, Tank 2 & $14.65 \pm 0.06$ \\
Run 2,Tank 4 & $13.92 \pm 0.03$ \\
Run 3 & \\
Tank 8 & $13.89 \pm 0.02$ \\
Tank 9 & $13.75 \pm 0.02$ \\
Tank 10 & $13.85 \pm 0.01$ \\
\hline
\end{tabular}

Table 2 Results of a linear mixed effects model testing the effects of temperature and sediment on sea urchin grazing with tank nested within experimental run as a random factor

\begin{tabular}{lrrrrr}
\hline Source & SS & MS & $\boldsymbol{d f}$ & $\boldsymbol{F}$-value & $\boldsymbol{P}$-value \\
\hline Temperature & 7465 & 7465 & 1 & 2.217 & 0.147 \\
Sediment & 163,530 & 163,530 & 1 & 48.561 & $<0.001$ \\
Temperature: sediment & 8087 & 8087 & 1 & 2.401 & 0.132 \\
\hline
\end{tabular}

Italics indicates significant $P$-value $(\alpha=0.05)$

within experimental run (3 runs) was included as a random factor. Tank was included in the analysis so that any procedural effect of including all replicates within the same tanks in the first two runs could be detected. Residuals plots were visually examined for normality and equal variance.

\section{Results and discussion}

Grazing rates were significantly different between the no sediment and high sediment treatments (Table 2, $F$-value $=48.561, P$-value $<0.001)$ and grazing rates were 89-94\% lower in the presence of high sediment (Fig. 1). Although there appeared to be a trend toward higher grazing rates with elevated temperature within no sediment treatments, this was not significant and there was no significant interaction between the sediment and temperature treatments (Table 2). The negative effects of sediment likely overpowered any positive effect of temperature on grazing rates. With a higher sample 


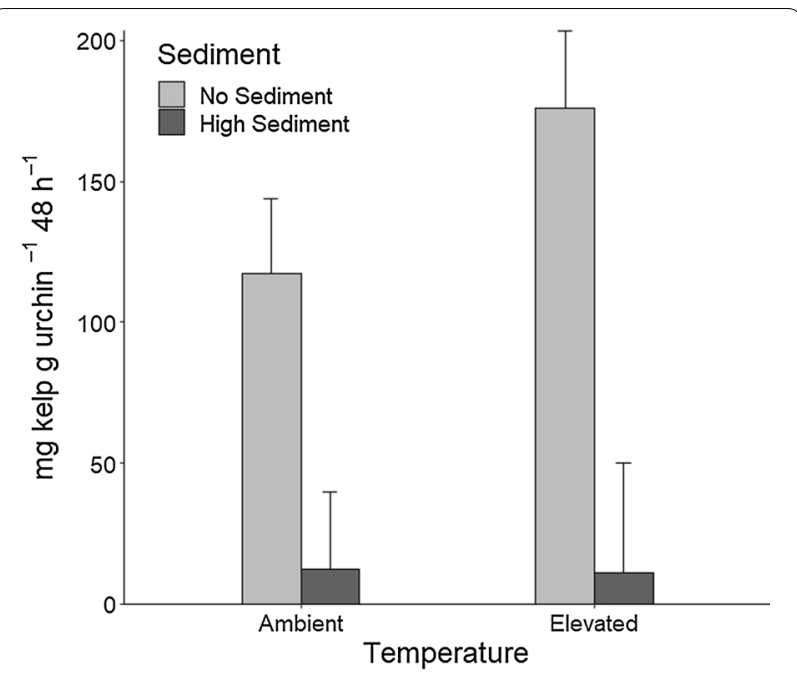

Fig. 1 Grazing rates of sea urchins in each treatment. Lines above bars show standard error from the linear mixed-effects model, $n=9$ for each treatment combination

Table 3 Variance and standard deviation associated with the random effects

\begin{tabular}{lcc}
\hline Random effects & Variance & $\begin{array}{l}\text { Standard } \\
\text { deviation }\end{array}$ \\
\hline Tank: experimental run & $<0.001$ & $<0.001$ \\
Experimental run & 992.6 & 31.5 \\
Residual & 3368.0 & 58.0 \\
\hline
\end{tabular}

size, a significant interaction between temperature and sediment may have been detected. Grazing rates varied among experimental runs and the highest grazing rates were observed during run 3 in the elevated temperature, no sediment treatment at $251.7 \mathrm{mg}$ kelp g urchin ${ }^{-1}$ $48 \mathrm{~h}^{-1}$ ( \pm SE 54.8, $n=3$ ) (Table 3, Additional file 1: Figure S1). Although urchins were fed to satiation daily until the starvation period, the length of time urchins were held in the laboratory previous to the start of the experiment may have contributed to the variation in grazing rates among experimental runs for the no sediment treatments (Additional file 1: Figure S1). As urchins used in later trials were held in the laboratory longer, they had longer to recover from the stress of collection and this reduced stress may have allowed their grazing to increase compared to earlier trials. Grazing rates below zero during run 2 for the high sediment treatments indicate that kelp in the no-urchin control jars had deteriorated over the course of the grazing trial. Temperature varied among tanks in the ambient treatments from $6.9^{\circ} \mathrm{C}( \pm \mathrm{SE}$ $0.019, n=56)$ to $9.8^{\circ} \mathrm{C}( \pm$ SE $0.209, n=51)$ (Table 1$)$ due to temperature changes in the flow-through seawater source. Temperature of the elevated treatment tanks was slightly higher in the first run than the remaining runs $\left(14.6{ }^{\circ} \mathrm{C} \pm\right.$ SE 0.060, $\left.n=56\right)$ (Table 1 ).

There was a significant depression of sea urchin grazing under high sediment load. Sea urchins in the high sediment treatment tended to stay on the sides or top of the experimental jars to avoid the settled sediment, which apparently prevented them from accessing the kelp, which itself was covered with only a thin layer of settled sediment. Sea urchins can survive with low food supplies for extended periods [36], and may be able to adapt to seasonally or temporarily high sedimentation rates by moving to microhabitats with less sediment. Although Strongylocentrotus droebachiensis can climb up the stipes of some kelps, such as Laminaria digitata [37] to avoid sediment, Saccharina latissima in glacially-influenced areas have short, flexible stipes and the blade lies prostrate along the bottom [38], so climbing onto S. latissima would not allow urchins to fully avoid sediment. While sediment cover on kelp pieces in this experiment was light compared to the bottom of the jar, sediment cover on the blades of S. latissima in nature can be substantial, even burying blades [39]. Lower grazer abundance is commonly observed in locations with high sedimentation, including glacial estuaries [21] and rocky intertidal and subtidal reefs near mining operations [40]. Sediment avoidance and grazing inhibition are potential mechanisms behind this pattern. In Plymouth, UK, experimental laboratory and field studies found that fine sediment inhibited limpet grazing and abundance patterns in the rocky intertidal were related to sediment deposition [41]. Field transplant experiments have shown that scouring and burial by sediments can cause high mortality of adult limpets [42]. Sediment may also limit grazer populations through negative effects on settlement and early life stage survival. For example, sedimentation reduces larval settlement and juvenile survival of the New Zealand urchin, Evechinus chloroticus [43]. Sedimentation in coastal vegetated habitats may increase in the future with continued glacial melt [44], increased precipitation [45], and soil erosion [24]. If sedimentation increases in kelp forests, sea urchin grazing pressure may decrease. Changes in macroalgal composition and abundance are likely to occur simultaneously with grazing pressure in response to increase sediment. In Alaska, kelp diversity is typically lower near points of glacial sediment input and the sediment-tolerant $S$. latissima is often the dominant kelp species [21, 46, 47]. Although extreme increases in sedimentation can result in loss of even this sedimenttolerant kelp, as in Norway where sediment deposition from frequent flooding resulted in the loss of $90 \%$ of $S$. latissima forests along the southern coast [48]. Although sedimentation affects sea urchin grazing rates, at high sedimentation rates the direct effects of sediment on 
macroalgae may be more important in affecting macroalgal composition and abundance.

In contrast to some previous studies, there was not a significant increase in sea urchin grazing rate with elevated temperature. Laboratory and field experiments on urchins in the Galapagos Islands found that increased temperature resulted in stronger top-down effects on algal biomass and sea urchin grazing rates were five times higher during the warm season compared to the cold season $[26,27]$. Increased temperature also increases urchin grazing rates on seagrass [49]. In a laboratory experiment in Australia, only small individuals of the urchin, Heliocidaris erythrogramma, were able to increase grazing rates to compensate for increased metabolic rate at future predicted temperature [50]. There are distinct differences in consumption rates of kelp recruits by sea urchins and herbivorous fish between warm and cool regions in Portugal [51]. In Norway, feed conversion ratios of juvenile S. droebachiensis held at 12 and $14{ }^{\circ} \mathrm{C}$ were higher than those at 6 and $10{ }^{\circ} \mathrm{C}$ [52]. However, in a short-term (48h) feeding trial using $S$. droebachiensis from the Gulf of Maine, grazing rates were lower at $20{ }^{\circ} \mathrm{C}$ than at 13 or $16.5^{\circ} \mathrm{C}$ [53]. Although differences in experimental design (i.e. starvation period, temperature, urchin size) make comparison of grazing rates to other studies difficult, grazing rates in this study seem to be lower than those observed in similar short-term lab experiments with $S$. droebachiensis ( 1-3 g kelp consumed in [53]; $0.8 \mathrm{~g}$ kelp consumed on average in McKay and Heck [54]). Strongylocentrotus droebachiensis experience higher temperatures at the southern part of their distribution than the higher temperature treatment used in this study $\left(14{ }^{\circ} \mathrm{C}\right)$, but marine invertebrates like $S$. droebachiensis are often adapted to local temperature regimes [55], so it could still be expected that their grazing rates increase at this temperature. The high temperature treatment used here was approximately $2{ }^{\circ} \mathrm{C}$ above mean summer high temperature in Kachemak Bay but a maximum temperature of $13.6^{\circ} \mathrm{C}$ was observed in recent years (2002-2014) [31] so S. droebachiensis in this area may have started adapting to these high temperatures. While there was not a significant interaction between elevated temperature and high sedimentation on grazing rate in this study, this could change with a more extreme temperature increase. There was a nonsignificant trend towards higher grazing rate at the higher temperature, no sediment treatment, and a significant effect of temperature may have been detected with higher replication. Grazing rates can also vary with season and reproductive status [56], and these factors are beyond the scope of this short-term experiment.

While many studies have been conducted to examine the effects of individual stressors associated with climate change on the survival or growth of individual species, investigating the impacts of multiple stressors on species interactions is critical to determining ecosystem responses [57, 58]. Changes in environmental conditions which affect marine invertebrate grazing can have cascading effects with consequences for habitat complexity and species abundance and diversity. For example, turfing, foliose, or filamentous macroalgae, which provide less complex habitat than kelps, can persist where the presence of sediments deters grazing [59-61]. This study indicates that grazing suppression by sedimentation may outweigh temperature-driven increases in grazing, at least at the modest temperature increase examined here, although further study with greater replication is needed. While this study was short-term, it indicates that even short-term pulses of sediment may significantly affect urchin grazing. Sedimentation is a dynamic process that is expected to change in many nearshore ecosystems and it is important to understand how these changes will interact with global changes in temperature to affect the role of grazers in coastal vegetated habitats. This study supports the hypothesis that sedimentation inhibits invertebrate grazing in high-sediment environments where macroalgae can persist, and illustrates the importance of considering such local stressors in the study of the effects of climate change on nearshore systems.

\section{Supplementary information}

Supplementary information accompanies this paper at https://doi. org/10.1186/s10152-019-0526-x.

Additional file 1: Figure S1. Grazing rates of sea urchins in each treatment and experimental run (figure legend). Lines above bars show standard error, $\mathrm{n}=3$ for each treatment in each experimental run. Grazing rates below zero during run 2 for the high sediment treatments indicate that kelp in the no-urchin control jars had deteriorated over the course of the grazing trial.

\section{Acknowledgements}

I would like to thank the staff at the Kasitsna Bay Laboratory for field and laboratory support and Brenda Konar, Katrin Iken, Lauren Sutton, and Kim PowellSchuster for their assistance in field collections. Comments on the manuscript from Tanja Schollmeier, Kerry Nickols, Jean-Sébastien Lauzon-Guay, Demetra Panos, and Nyssa Silbiger were greatly appreciated. I thank the anonymous reviewers for their comments. This research was supported by a University of Alaska Fairbanks Global Change Student Research Grant award with funds from the Cooperative Institute for Alaska Research. Sea urchins and kelp were collected with permission of the State of Alaska Department of Fish and Game (Permit Number CF-17-069).

\section{Authors' contributions}

I am the sole author of this manuscript. The author read and approved the final manuscript.

\section{Funding}

This research was supported by a University of Alaska Fairbanks Global Change Student Research Grant award with funds from the Cooperative Institute for Alaska Research. 


\section{Availability of data and materials}

The datasets used during the current study are available from the corresponding author on request.

\section{Ethics approval and consent to participate}

Sea urchins and kelp were collected with permission of the State of Alaska Department of Fish and Game (Permit Number CF-17-069). No human subjects or vertebrate animals were used in this study.

\section{Consent for publication}

Not applicable.

\section{Competing interests}

The authors declare that they have no competing interests.

Received: 21 December 2018 Accepted: 30 August 2019 Published online: 11 September 2019

\section{References}

1. Teagle H, Hawkins SJ, Moore PJ, Smale DA. The role of kelp species as biogenic habitat formers in coastal marine ecosystems. J Exp Mar Bio Ecol. 2017:492:81-98.

2. Wernberg T, Krumhansl K, Filbee-Dexter K, Pedersen MF. Status and trends for the world's kelp forests. In: Sheppard C, editor. World Seas: an environmental evaluation, ecological issues and environmental impacts, vol. 3. 2nd ed. Amsterdam: Elsevier; 2019. p. 57-78. https://doi. org/10.1016/b978-0-12-805052-1.00003-6.

3. Graham MH. Effects of local deforestation on the diversity and structure of southern California giant kelp forest food webs. Ecosystems. 2004;7:341-57.

4. Ling SD. Range expansion of a habitat-modifying species leads to loss of taxonomic diversity: a new and impoverished reef state. Oecologia. 2008;156:883-94. https://doi.org/10.1007/s00442-008-1043-9.

5. Filbee-Dexter K, Scheibling RE. Sea urchin barrens as alternative stable states of collapsed kelp ecosystems. Mar Ecol Prog Ser. 2014;495:1-25.

6. Poloczanska ES. Global imprint of climate change on marine life. Nat Clim Change. 2013;3:919-25. https://doi.org/10.1038/NCLIMATE1958.

7. IPCC. Climate change 2014: impact, adaptation and vulnerability. In: Working group II contribution to the IPCC 5th Assessment Report. Cambridge; 2014

8. Brown JH, Gillooly JF, Allen AP, Savage VM, West GB. Toward a metabolic theory of ecology. Ecology. 2004;85:1771-89. https://doi. org/10.1890/03-9000.

9. Petraitis PS. Effects of body size and water temperature on grazing rates of four intertidal gastropods. Aust J Ecol. 1992;17:409-14.

10. Sanford E. Water temperature, predation, and the neglected role of physiological rate effects in rocky intertidal communities. Integr Comp Biol. 2002;42:881-91.

11. Brown MB, Edwards MS, Kim KY. Effects of climate change on the physiology of giant kelp, Macrocystis pyrifera, and grazing by purple urchin, Strongylocentrotus purpuratus. Algae. 2014;29:203-15. https://doi. org/10.4490/algae.2014.29.3.203.

12. Ling SD, Johnson CR, Ridgway K, Hobday AJ, Haddon M. Climate-driven range extension of a sea urchin: inferring future trends by analysis of recent population dynamics. Glob Change Biol. 2009;15:719-31. https:// doi.org/10.1111/j.1365-2486.2008.01734.x.

13. Christie H, Gundersen H, Rinde E, Filbee-Dexter K, Norderhaug KM, Pedersen T, et al. Can multitrophic interactions and ocean warming influence large-scale kelp recovery? Ecol Evol. 2019;9:2847-62. https://doi. org/10.1002/ece3.4963.

14. Goff JR. A chronology of natural and anthropogenic influences on coastal sedimentation, New Zealand. Mar Geol. 1997;138:105-17. https://doi. org/10.1016/S0025-3227(97)00018-2.

15. Scavia D, Field JC, Boesch DF, Buddemeier RW, Burkett V, Cayan DR, et al. Climate change impacts on U. S. coastal and marine ecosystems. Estuaries. 2002;25:149-64

16. Airoldi L, Beck MW. Loss, status and trends for coastal marine habitats of Europe. Oceanogr Mar Biol An Annu Rev. 2007;35:345-405.
17. Neal EG, Hood E, Smikrud K. Contribution of glacier runoff to freshwater discharge into the Gulf of Alaska. Geophys Res Lett. 2010;37:1-5.

18. Wiencke C, Clayton MN, Gómez I, Iken K, Lüder UH, Amsler CD, et al. Life strategy, ecophysiology and ecology of seaweeds in polar waters. Rev Environ Sci Bio/Technol. 2007;6:95-126. https://doi.org/10.1007/s1115 7-006-9106-z

19. Bonsell C, Dunton $\mathrm{KH}$. Long-term patterns of benthic irradiance and kelp production in the central Beaufort sea reveal implications of warming for Arctic inner shelves. Prog Oceanogr. 2018;162:160-70. https://doi. org/10.1016/J.POCEAN.2018.02.016.

20. Fritz M, Vonk JE, Lantuit H. Collapsing arctic coastlines. Nat Clim Change. 2017;7:6-7. https://doi.org/10.1038/nclimate3188.

21. Traiger SB, Konar B. Mature and developing kelp bed community composition in a glacial estuary. J Exp Mar Bio Ecol. 2018;501:26-35.

22. Airoldi $\mathrm{L}$. The effects of sedimentation on rocky coast assemblages. Oceanogr Mar Biol. 2003;41:161-236.

23. Filbee-Dexter K, Wernberg T, Fredriksen S, Norderhaug KM, Pedersen MF. Arctic kelp forests: diversity, resilience and future. Glob Planet Change. 2019;172:1-14. https://doi.org/10.1016/J.GLOPLACHA.2018.09.005.

24. Nearing MA, Pruski FF, O'Neal MR. Expected climate change impacts on soil erosion rates: a review. J Soil Water Conserv. 2004;59:43-50.

25. Ling SD, Scheibling RE, Rassweiler A, Johnson CR, Shears N, Connell SD, et al. Global regime shift dynamics of catastrophic sea urchin overgrazing. Philos Trans R Soc B Biol Sci. 2015;370:20130269. https://doi.org/10.1098/ rstb.2013.0269.

26. Carr LA, Bruno JF. Warming increases the top-down effects and metabolism of a subtidal herbivore. PeerJ. 2013;1:1-15. https://doi.org/10.7717/ peerj.109.

27. Carr LA, Gittman RK, Bruno JF. Temperature influences herbivory and alga biomass in the Galapagos Islands. Front Mar Sci. 2018;5:1-10.

28. Provost EJ, Kelaher BP, Dworjanyn SA, Russell BD, Connell SD, Ghedini G et al. Climate-driven disparities among ecological interactions threaten kelp forest persistence. Glob Change Biol. 2017;23:353-61. https://doi. org/10.1111/gcb.13414.

29. Hart MW, Scheibling RE. Heat waves, baby booms, and the destruction of kelp beds by sea urchins. Mar Biol. 1988;99:167-76. https://doi. org/10.1007/BF00391978

30. Team NA. Climate change impacts on the united states. New York: Cambridge University Press; 2000.

31. Lind A, Konar B. Effects of abiotic stressors on kelp early life-history stages Algae. 2017;32:223-33.

32. Royer TC, Grosch CE. Ocean warming and freshening in the northern Gulf of Alaska. Geophys Res Lett. 2006;33:1-6.

33. Delorme NJ, Sewell MA. Effects of warm acclimation on physiology and gonad development in the sea urchin Evechinus chloroticus. Comp Biochem Physiol Part A Mol Integr Physiol. 2016;198:33-40.

34. Bates D, Maechler M, Bolker B, Walker S. Fitting linear mixed-effects models using Ime4. J Stat Softw. 2015;67:1-48.

35. RStudio Team. RStudio: integrated development for R. Boston: RStudio Team; 2016.

36. Bernstein BB, Schroeter SC, Mann KH. Sea urchin (Strongylocentrotus droebachiensis) aggregating behavior investigated by a subtidal multifactorial experiment. Can J Fish Aquat Sci. 1983:40:1975-86.

37. Lauzon-Guay J, Scheibling R. Behaviour of sea urchin Strongylocentrotus droebachiensis grazing fronts: food-mediated aggregation and densitydependent facilitation. Mar Ecol Prog Ser. 2007;329:191-204. https://doi org/10.3354/meps329191.

38. Spurkland T, Iken K. Seasonal growth patterns of Saccharina latissima (Phaeophyceae, Ochrophyta) in a glacially-influenced subarctic estuary. Phycol Res. 2012;60:261-75.

39. Roleda MY, Dethleff D, Wiencke C. Transient sediment load on blades of Arctic Saccharina latissima can mitigate UV radiation effect on photosynthesis. Polar Biol. 2008;31:765-9.

40. Pulfrich A, Parkins CA, Branch GM, Bustamante $\mathrm{RH}$, Velasquez CR. The effects of sediment deposits from Namibian diamond mines on intertidal and subtidal reefs and rock lobster populations. Aquat Conserv Mar Freshw Ecosyst. 2003;13:257-78.

41. Airoldi L, Hawkins SJ. Negative effects of sediment deposition on grazing activity and survival of the limpet Patella vulgata. Mar Ecol Prog Ser. 2007;332:235-40. https://doi.org/10.3354/meps332235. 
42. Robles C. Disturbance and predation in an assemblage of herbivorous Diptera and algae on rocky shores. Oecologia. 1982;54:23-31.

43. Walker JW. Effects of fine sediments on settlement and survival of the sea urchin Evechinus chloroticus in northeastern New Zealand. Mar Ecol Prog Ser. 2007;331:109-18.

44. Bliss A, Hock R, Radić V. Global response of glacier runoff to twenty-first century climate change. J Geophys Res Earth Surf. 2014;119:717-30. https ://doi.org/10.1002/2013JF002931.

45. Maloney ED, Camargo SJ, Chang E, Colle B, Fu R, Geil KL, et al. North American climate in CMIP5 experiments: Part III: Assessment of twentyfirst-century projections. J Clim. 2014;27:2230-70.

46. Pirtle JL, Ibarra SN, Eckert GL. Nearshore subtidal community structure compared between inner coast and outer coast sites in Southeast Alaska. Polar Biol. 2012;35:1889-910.

47. Spurkland T, Iken K. Kelp bed dynamics in estuarine environments in subarctic Alaska. J Coast Res. 2011;275:133-43.

48. Bogen J. The impact of environmental changes on the sediment loads of Norwegian rivers. CATENA. 2009;79:251-6. https://doi.org/10.1016/j.caten a.2009.07.003.

49. Burnell O, Russell B, Irving A, Connell S. Eutrophication offsets increased sea urchin grazing on seagrass caused by ocean warming and acidification. Mar Ecol Prog Ser. 2013;485:37-46. https://doi.org/10.3354/meps1 0323.

50. Carey N, Harianto J, Byrne M. Sea urchins in a high- $\mathrm{CO}_{2}$ world: partitioned effects of body size, ocean warming and acidification on metabolic rate. J Exp Biol. 2016;219:1178-86.

51. Franco J, Wernberg T, Bertocci I, Duarte P, Jacinto D, Vasco-Rodrigues N, et al. Herbivory drives kelp recruits into 'hiding' in a warm ocean climate. Mar Ecol Prog Ser. 2015;536:1-9. https://doi.org/10.3354/meps11445.

52. Siikavuopio SI, James $P$, Lysne H, Saether BS, Samuelsen TA, Mortensen A. Effects of size and temperature on growth and feed conversion of juvenile green sea urchin (Strongylocentrotus droebachiensis). Aquaculture. 2012:354-355:27-30.
53. Wheeler M. Temperature dependent feeding habits of the green sea urchin S. droebachiensis, on L. longicruris. JUST. 2017;5:1-5.

54. McKay K, Heck K. Presence of the Jonah crab Cancer borealis significantly reduces kelp consumption by the green sea urchin Strongylocentrotus droebachiensis. Mar Ecol Prog Ser. 2008;356:295-8. https://doi. org/10.3354/meps07238.

55. Sanford E, Kelly MW. Local adaptation in marine invertebrates. Ann Rev Mar Sci. 2011;3:509-35. https://doi.org/10.1146/annurev-marine-12070 9-142756.

56. Scheibling RE, Hatcher BG. Ecology of Strongylocentrotus droebachiensis In: Lawrence JM, editor. Edible sea urchins: biology and ecology. Amsterdam: Elsevier; 2007. p. 353-92.

57. Harley CDG, Anderson KM, Demes KW, Jorve JP, Kordas RL, Coyle TA, et al. Effects of climate change on global seaweed communities. J Phycol. 2012;48:1064-78.

58. Doney SC, Ruckelshaus M, Duffy JE, Barry JP, Chang F, English CA, et al. Climate change impacts on marine ecosystem. Ann Rev Mar Sci. 2012:4:4.1-4.27.

59. D'Antonio CM. Role of sand in the domination of hard substrata by the intertidal alga. Mar Ecol Prog Ser. 1986;27:263-75.

60. Branch GM, Eekhout S, Bosman AL. Short-term effects of the 1988 Orange River floods on the intertidal rocky-shore communities of the open coast. Trans R Soc South Afr. 1990;47:331-54. https://doi.org/10.1080/00359 199009520246

61. Trowbridge CD. Mesoherbivory: the ascoglossan sea slug Placida dentritica may contribute to the restricted distribution of its algal host. Mar Ecol Prog Ser. 1992;83:207-20.

\section{Publisher's Note}

Springer Nature remains neutral with regard to jurisdictional claims in published maps and institutional affiliations.
Ready to submit your research? Choose BMC and benefit from:

- fast, convenient online submission

- thorough peer review by experienced researchers in your field

- rapid publication on acceptance

- support for research data, including large and complex data types

- gold Open Access which fosters wider collaboration and increased citations

- maximum visibility for your research: over $100 \mathrm{M}$ website views per year

At $\mathrm{BMC}$, research is always in progress.

Learn more biomedcentral.com/submissions 